\section{Abscisic Acid Application Enhances Drought Stress Tolerance in Bedding Plants}

\author{
Nicole L. Waterland ${ }^{1}$ \\ Department of Horticulture and Crop Science, The Ohio Agricultural \\ Research and Development Center, The Ohio State University, Wooster, \\ $\mathrm{OH} 44691$
}

Craig A. Campbell

Field Research and Development, Valent BioSciences Corporation, Orlando, FL 32818

John J. Finer and Michelle L. Jones ${ }^{2}$

Department of Horticulture and Crop Science, The Ohio Agricultural Research and Development Center, The Ohio State University, Wooster, $\mathrm{OH} 44691$

Additional index words. ABA, floriculture, leaf chlorosis, postproduction, shelf life extension, wilt status

\begin{abstract}
Drought stress is a major cause of postproduction decline in bedding plants. The plant hormone abscisic acid (ABA) regulates drought stress responses by mediating stomatal closure, thereby reducing transpirational water loss. Exogenous ABA applications delay wilting and allow plants to survive short periods of severe drought. The effectiveness of the ABA biochemical, s-ABA (ConTego ${ }^{\mathrm{TM}}$; Valent BioSciences Corp., Libertyville, IL), at delaying wilting and extending shelf life during drought stress was evaluated in six bedding plant species. Spray and drench applications of 0 or $500 \mathrm{mg} \cdot \mathrm{L}^{-1}$ s-ABA were applied to Impatiens walleriana (impatiens), Pelargonium $\times$ hortorum (seed geranium), Petunia $\times$ hybrida (petunia), Tagetes patula (marigold), Salvia splendens (salvia), and Viola $\times$ wittrockiana (pansy). Water was subsequently withheld and wilting symptoms were compared between treated and control plants. S-ABA applications delayed wilting in all crops by 1.7 to 4.3 days. Leaf chlorosis was observed after s-ABA application in drought-stressed seed geraniums, marigolds, and pansies. In seed geraniums and marigolds, the drought stress itself resulted in leaf chlorosis that was equivalent to or more severe than the s-ABA application alone. In pansies, s-ABA applications induced leaf chlorosis that was more severe than the drought treatment. Overall, s-ABA was consistently effective at reducing water loss and extending shelf life for all species treated. Applications of s-ABA to bedding plants before shipping and retailing would allow plants to maintain marketability even under severe drought stress conditions.
\end{abstract}

Received for publication 13 Oct. 2009. Accepted for publication 11 Jan. 2010.

This research was funded by the OSU D.C. Kiplinger Floriculture Endowment, the Valent BioSciences Corporation, and the Gladys Wittmeyer Knox-Gene Wittmeyer Scholarship. Salaries and research support were provided in part by State and Federal funds appropriated to the Ohio Agricultural Research and Development Center, The Ohio State University. Journal Article Number HCS 09-15.

We thank Green Circle Growers Inc. for their donation of plant material.

The information in this publication is for educational purposes only. Mention of a trademark, proprietary product, or vendor does not constitute a guarantee or warranty of the product nor does it imply approval or disapproval to the exclusion of other products or vendors that may also be suitable. ${ }^{1}$ Current address: Division of Plant and Soil Sciences, West Virginia University, Morgantown, WV 26505 .

${ }^{2}$ To whom reprint requests should be addressed; e-mail jones.1968@osu.edu.
Floriculture crops represent a $\$ 4.2$ billion industry in the United States with bedding plants accounting for $\approx 44 \%$ of their total wholesale value (USDA, 2009). In the last 17 years, there has been a change in the retailing of floriculture crops as customers purchase more bedding and garden plants from bigbox retailers (mass merchandisers and club centers) and general retailers (department stores and supermarkets) and less from traditional garden centers and florists (Yue and Behe, 2008). Subsequently, the shipping and retailing of these plants may occur farther from the site of production, making proper postproduction care and handling increasingly important to ensure that customers receive the best quality plants (Starman et al., 2007). During shipping and retailing, plants may be exposed to harsh environmental conditions, including high temperatures and irregular irrigation, which cause rapid substrate drying and plant wilting. These drought-stressed plants quickly become un- desirable to the customer. It is estimated that $5 \%$ of the plant material retailing at independent garden centers may become unsalable, whereas postproduction losses at the big-box retailers may be as high as $10 \%$ to $15 \%$ (Healy, 2009).

Very little research has been conducted on the postproduction care and handling of floriculture crops. Although environmental conditions during greenhouse production are optimized for plant growth and development, postproduction environments are often less than ideal. Floriculture crops suffer stress from high temperature, low light, nutrient deficiencies, and water deprivation during shipping and retailing (Armitage, 1993; Starman et al., 2007). Toning by reducing fertility and available water during the last 2 weeks of greenhouse production has been promoted as a means of "hardening off" plants so that they are less susceptible to the environmental stresses experienced after production (Armitage, 1993; Starman et al., 2007). Reduced end-of-production fertilization effectively increases the quality and shelf life of a number of containerized vegetative annuals (Beach et al., 2009). Although this production practice enhances the value of many floriculture crops under standard shipping and retailing conditions, there is no experimental evidence to indicate whether this shelf life extension would be observed if plants experienced severe drought stress.

Plant wilting can be caused by a combination of enhanced water loss and inadequate watering, and it is a major cause of postproduction decline in greenhouse crops (Barrett and Campbell, 2006). The plant hormone abscisic acid (ABA) plays a role in plant responses to environmental stresses, and $\mathrm{ABA}$ applications decrease water loss and enhance drought tolerance (Leskovar and Cantliffe, 1992; Yamazaki et al., 1995). The use of chemicals to reduce water loss in floriculture crops has shown variable results, but new formulations of ABA are now available for commercial growers to use as a plant growth regulator (Barrett and Campbell, 2006).

Recent research has focused on the use of concentrated $\mathrm{ABA}$ or $\mathrm{ABA}$ analogs as a means of maintaining the marketability of horticulture crops by reducing drought stress symptoms (Blanchard et al., 2007; Kim and van Iersel, 2008; Monteiro et al., 2001; Sharma et al., 2006). ABA analogs have been used to effectively reduce water use and extend the shelf life of tomato (Solanum lycopersicon), snapdragon (Antirrhinum majus), and nasturtium (Tropelaum majus) transplants (Sharma et al., 2006). The application of exogenous ABA during spring/ summer production periods also reduces respiration and water loss in potted miniature rose (Rose hybrida L.) and results in increased flower longevity (Monteiro et al., 2001). Experiments with a new ABA formulation (s-ABA; ConTego ${ }^{\mathrm{TM}}$; Valent BioSciences Corp.) have shown that sprench (spray to runoff) applications of 125 or $250 \mathrm{mg} \cdot \mathrm{L}^{-1}$ delay drought-induced wilting symptoms in 


\begin{tabular}{|c|c|c|c|c|c|c|}
\hline \multirow[b]{4}{*}{ Species and cultivar } & \multicolumn{6}{|c|}{ Concn and method of application of s-ABA $\left(\mathrm{mg} \cdot \mathrm{L}^{-1}\right)$} \\
\hline & \multicolumn{6}{|c|}{ Time before wilt (days) } \\
\hline & \multicolumn{3}{|c|}{ Drench } & \multicolumn{3}{|c|}{ Spray } \\
\hline & 0 & 500 & Shelf life extension & 0 & 500 & Shelf life extension \\
\hline Impatiens walleriana 'Xtreme Lavender' & $4.3 \mathrm{~b}$ & $7.0 \mathrm{a}$ & 2.7 & $4.0 \mathrm{~b}$ & $6.7 \mathrm{a}$ & 2.7 \\
\hline Pelargonium $\times$ hortorum 'Maverick Red' & $3.3 \mathrm{~b}$ & $7.0 \mathrm{a}$ & 3.7 & $3.7 \mathrm{~b}$ & $6.7 \mathrm{a}$ & 3.0 \\
\hline Petunia $\times$ hybrida 'Ultra Red' & $5.7 \mathrm{~b}$ & $10.0 \mathrm{a}$ & 4.3 & $5.3 \mathrm{~b}$ & $9.3 \mathrm{a}$ & 4.0 \\
\hline Tagetes patula 'Bonanza Orange' & $3.7 \mathrm{c}$ & $6.7 \mathrm{a}$ & 3.0 & $3.3 \mathrm{c}$ & $5.0 \mathrm{~b}$ & 1.7 \\
\hline Salvia splendens 'Picante Scarlet' & $5.3 \mathrm{~b}$ & $8.0 \mathrm{a}$ & 2.7 & $5.3 \mathrm{~b}$ & $7.7 \mathrm{a}$ & 2.4 \\
\hline Viola $\times$ wittrockiana 'Bingo Rose Frost' & $4.3 \mathrm{~b}$ & $6.7 \mathrm{a}$ & 2.4 & $4.0 \mathrm{~b}$ & $7.0 \mathrm{a}$ & 3.0 \\
\hline
\end{tabular}

${ }^{2}$ Values are an average of the number of days from Day 0 that it took each plant to show visible symptoms of wilt which was a rating of 3 (starting to wilt) on the wilt status rating scale of 1 to 5 . Values are means of four replications $(\mathrm{n}=4)$. Values in rows followed by different letters are statistically different at $P \leq 0.05$ (least significant difference test).

seven of nine species of bedding plants that were evaluated (Blanchard et al., 2007). Shelf life extensions for the seven species varied from 1.1 to $5.8 \mathrm{~d}$ (Blanchard et al., 2007). Overall, exogenous ABA applications have the potential to enhance drought tolerance in plants, but many questions remain about the optimal application methods and effectiveness across different plant species.

The goal of this research was to investigate the effectiveness and use of s-ABA for reducing postproduction decline resulting from water stress. The specific research objectives were 1) to determine whether the application of s-ABA could effectively reduce drought-induced wilting in a variety of bedding plants; 2) to determine if the method of application influences effectiveness; and 3) to document and quantify any side effects that result from exogenous applications of $\mathrm{ABA}$.

\section{Materials and Methods}

Sources and handling of plant material. Six species of the most popular bedding plants were selected to investigate the effectiveness of s-ABA application for enhancing drought tolerance. Bedding plants were obtained from Green Circle Growers Inc. (Oberlin, $\mathrm{OH}$ ) and The Greenhouse Shoppe (Wooster, OH). Species included Impatiens walleriana 'Xtreme Lavender', Pelargonium $\times$ hortorum 'Maverick Red', Petunia $\times$ hybrida 'Ultra Red', Tagetes patula 'Bonanza Orange', Salvia splendens 'Picante Scarlet', and Viola $\times$ wittrockiana 'Bingo Rose Frost'. All bedding plants were obtained as 508-cell packs $\left(111.6 \mathrm{~cm}^{3} /\right.$ cell) except for salvia (72plug tray; $41.6 \mathrm{~cm}^{3} / \mathrm{cell}$ ) and seed geraniums (finished $10-\mathrm{cm}$ pots). All plants except the seed geraniums were transplanted to $11-\mathrm{cm}$ pots containing soilless greenhouse media (Promix BX; Premier Horticulture, Quebec, Canada). Plants were grown under normal greenhouse conditions in Wooster, $\mathrm{OH}$, from 27 May to 19 June 2009. Plants were maintained using natural irradiance with supplemental irradiance provided by high-pressure sodium and metal halide lamps (GLX/GLS e-systems GROW lights; PARSource, Petaluma, CA) with average photosynthetic photon flux of $\approx 200 \mu \mathrm{mol} \cdot \mathrm{m}^{-2} \cdot \mathrm{s}^{-1}$ from 0500 to 1900 HR daily. Greenhouse temperatures were $23.4 / 17.5{ }^{\circ} \mathrm{C}$ day/night with daytime relative humidity of $66.7 \% \pm 10.5 \%$. Plants were irrigated daily with Peters Excel ${ }^{\circledR}$ Allpurpose $15 \mathrm{~N}-2.15 \mathrm{P}-12.5 \mathrm{~K}$ (The Scotts Co., Marysville, $\mathrm{OH}$ ) at $200 \mathrm{mg} \mathrm{N} / \mathrm{L}$. This was reduced to $100 \mathrm{mg} \mathrm{N} / \mathrm{L} 1$ week before flowering. All species were treated with s-ABA (ConTego $^{\text {TM}}$; Valent BioSciences Corp., Libertyville, IL) when they reached a marketable stage of one to two open flowers per plant. Plants were watered to field capacity $12 \mathrm{~h}$ before an application of s-ABA. Drench applications were applied based on the manufacturer's recommendations (volume of $60 \mathrm{~mL}$ ) at the rate of 0 or $500 \mathrm{mg} \cdot \mathrm{L}^{-1} \mathrm{~s}-\mathrm{ABA}$ and sprays (volume of $\approx 28 \mathrm{~mL}$ ) at the rate of 0 or $500 \mathrm{mg} \cdot \mathrm{L}^{-1} \mathrm{~s}-\mathrm{ABA}$ with the addition of $0.05 \% \mathrm{CapSil}^{\circledR}$ (Aquatrols Corporation of America, Inc., Cherry Hill, NJ). Spray applications were applied with a Regulator Bakpak $^{\circledR}$ sprayer (H.D. Hudson Manufacturing Company, Chicago, IL). All plants were held in the greenhouse during subsequent evaluations. Half of the bedding plants were
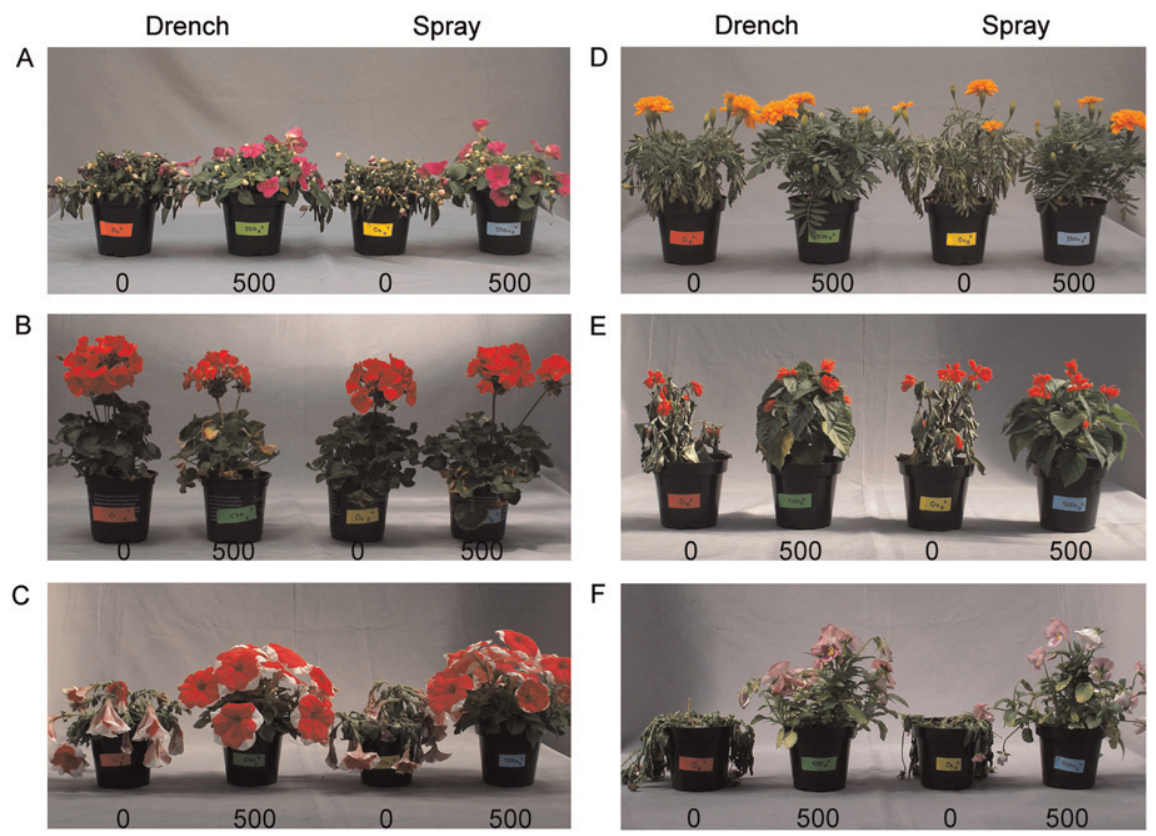

Fig. 1. Six species of bedding plants treated with either 0 or $500 \mathrm{mg} \cdot \mathrm{L}^{-1} \mathrm{~s}-\mathrm{ABA}$ drench or spray (from left to right in each photograph). Plants were drought-stressed until s-ABA-treated plants began to wilt. Images are of Impatiens walleriana 'Xtreme Lavender' (impatiens) (A), Pelargonium Xhortorum 'Maverick Red' (seed geranium) (B), Petunia $\times$ hybrida 'Ultra Red' (petunia) (C), Tagetes patula 'Bonanza Orange' (marigold) (D), Salvia splendens 'Picante Scarlet' (salvia) (E), and Viola $\times$ wittrockiana 'Bingo Pink Frost' (pansy) (F). Images are representative of all replications and were taken at $5 \mathrm{~d}$ after application of s-ABA and drought stress for all crops except seed geranium (B) which was taken at $6 \mathrm{~d}$, petunia (C) which was at $7 \mathrm{~d}$, and marigold (D) which was at $4 \mathrm{~d}(\mathrm{n}=4)$. 
completely green with no sign of chlorosis, 10: having $10 \%$ or less leaf chlorosis, $9: 11 \%$ to $20 \%, 8: 21 \%$ to $30 \%, 7: 31 \%$ to $40 \%, 6$ : $41 \%$ to $50 \%, 5: 51 \%$ to $60 \%, 4: 61 \%$ to $70 \%$, 3: $71 \%$ to $80 \%, 2: 81 \%$ to $90 \%$, and $1: 91 \%$ to $100 \%$ chlorosis. means of four plants in a completely randomized block design. Eleven-centimeter bedding plants were blocked by watering regiment, continually watered verses droughtstressed, and by replication. Values obtained from visual observations were analyzed by using Proc GLM (generalized linear model) with least significant different means separation. Values were analyzed by SAS (Statistical Analysis System, SAS Institute, Inc., Cary, NC; SAS Institute, Inc., 2002-2003).

\section{Results}

Wilt status and visual observations of bedding plants. The application of a 500 $\mathrm{mg} \cdot \mathrm{L}^{-1} \mathrm{~s}-\mathrm{ABA}$ spray or drench to drought-
Statistical analysis. Reported values are

stressed plants delayed visible wilting in all treated bedding plants and resulted in a subsequent increase in shelf life of 1.7 to $4.3 \mathrm{~d}$ depending on the species (Table 1; Figs. 1 and 2). In drought-stressed plants of all species, the control plants wilted before those sprayed or drenched with $500 \mathrm{mg} \cdot \mathrm{L}^{-1} \mathrm{~s}-\mathrm{ABA}$ $(P \leq 0.05)$ (Figs. 1 and 2). At the end of the drought stress treatment, impatiens, petunia, and marigold maintained higher wilt status ratings (i.e., more turgid) with drench versus spray applications of $500 \mathrm{mg} \cdot \mathrm{L}^{-1} \mathrm{~s}-\mathrm{ABA}$ $(P \leq 0.05)$ (Fig. 2). Pansy maintained higher turgor with spray applications $(P \leq 0.05)$ (Fig. 2). However, in all species except for marigold, there was no difference in the shelf life extension between spray and drench applications (Table 1). Drench applications of s-ABA on marigolds resulted in a longer shelf life extension than spray applications $(P \leq 0.05)$ (Table 1). Overall, the s-ABA applications were most effective at delaying visual wilting symptoms in petunia, resulting in a shelf life extension from $4.0 \mathrm{~d}$ (spray)

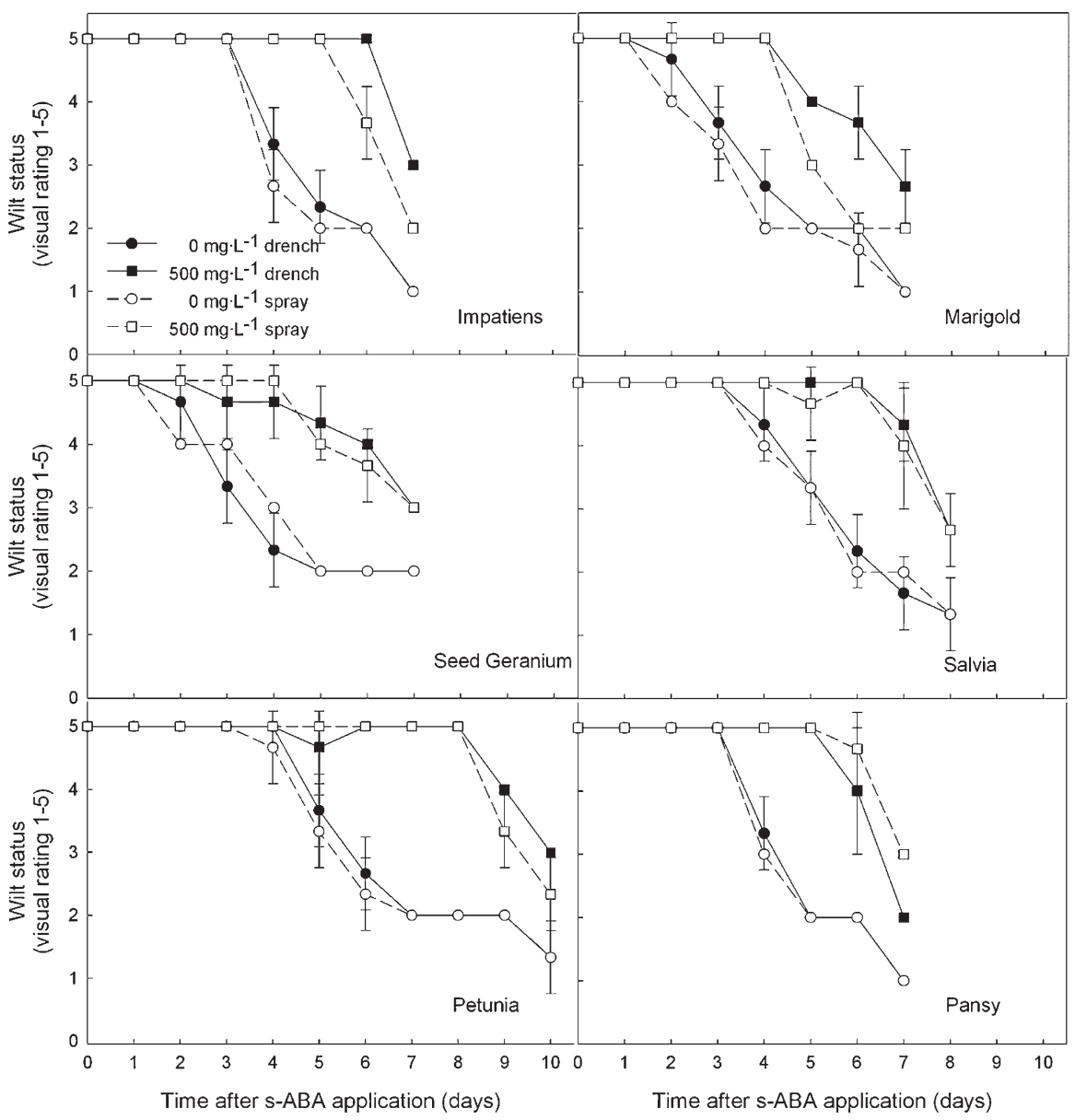

Fig. 2. Wilt status ratings of six species of bedding plants that received either a drench or spray application of 0 or $500 \mathrm{mg} \cdot \mathrm{L}^{-1} \mathrm{~s}-\mathrm{ABA}$. Wilt status ratings were taken daily over the course of the drought stress. Plants were drought-stressed until all s-ABA-treated plants began to show visual symptoms of wilt. Day 0 observations were taken just before s-ABA application and at the start of the drought stress. Water was withheld for $7 \mathrm{~d}$ for Impatiens walleriana 'Xtreme Lavender' (impatiens), Pelargonium xhortorum 'Maverick Red' (seed geranium), Tagetes patula 'Bonanza Orange' (marigold), and Viola $\times$ wittrockiana 'Bingo Pink Frost' (pansy); $8 \mathrm{~d}$ for Salvia splendens 'Picante Scarlet' (salvia); and $10 \mathrm{~d}$ for Petunia $\times$ hybrida 'Ultra Red' (petunia). Visual wilt status ratings were from 1 to 5 with 5 being completely turgid, 4 soft to the touch, 3 starting to wilt, 2 wilted with complete loss of turgor, and 1 wilted to the point that leaves are dry and brittle. Values are the mean of four plants $(n=4)$. to $4.3 \mathrm{~d}$ (drench) over the controls $\left(0 \mathrm{mg} \cdot \mathrm{L}^{-1}\right.$ s-ABA) (Table 1; Fig. 2). s-ABA application was the least effective on marigold, extending shelf life by $1.7 \mathrm{~d}$ (spray) and $3.0 \mathrm{~d}$ (drench) over the controls $\left(0 \mathrm{mg} \cdot \mathrm{L}^{-1} \mathrm{~s}-\mathrm{ABA}\right)$ (Table 1; Fig. 2). Seed geraniums showed curling and graying of the leaves, and wilting symptoms were not as obvious as those observed in the other species (Fig. 1B). sABA application resulted in a 3- (spray) to 3.7- (drench) day extension in the shelf life of seed geraniums. All other species had a similar 2- to 3-d increase in shelf life resulting from delays in drought-induced wilting $(\mathrm{Ta}-$ ble 1; Fig. 2). s-ABA-treated plants that were rewatered after the drought stress recovered and in many cases were indistinguishable from the continually watered control plants.

Leaf chlorosis of 11-cm finished bedding plants. Although applications of s-ABA were effective at delaying wilting, they also resulted in leaf chlorosis (i.e., yellowing) on seed geranium, marigold, and pansy (Fig. 3). Continually watered seed geraniums had more severe leaf chlorosis with drench application of s-ABA, whereas spray applications resulted in more severe chlorosis for pansies $(P \leq 0.05)$ (Fig. 4). Continually watered marigolds treated with $500 \mathrm{mg} \cdot \mathrm{L}^{-1} \mathrm{~s}-\mathrm{ABA}$ spray or drench resulted in $10 \%$ to $15 \%$ more leaf chlorosis with no differences observed between spray and drench applications (Fig. 4). Seed geraniums and marigolds under drought stress without s-ABA treatment also developed leaf chlorosis (Fig. 4). Drought-stressed seed geraniums developed more severe leaf chlorosis without s-ABA (0 $\mathrm{mg} \cdot \mathrm{L}^{-1} \mathrm{~s}-\mathrm{ABA}$ spray and drench) than with $\mathrm{s}-\mathrm{ABA}$ treatment $\left(500 \mathrm{mg} \cdot \mathrm{L}^{-1} \mathrm{~s}-\mathrm{ABA}\right.$ spray and drench) (Fig. 4). For droughtstressed marigolds, there was no difference in the severity of leaf chlorosis between control $\left(0 \mathrm{mg} \cdot \mathrm{L}^{-1} \mathrm{~s}-\mathrm{ABA}\right.$ spray and drench) or s-ABA-treated (500 mg. $\mathrm{L}^{-1} \mathrm{~s}$-ABA spray and drench) plants (Fig. 4). Drought-stressed and continually watered pansies treated with $500 \mathrm{mg} \cdot \mathrm{L}^{-1} \mathrm{~s}-\mathrm{ABA}$ had $10 \%$ to $25 \%$ more leaf chlorosis then nontreated controls $\left(0 \mathrm{mg} \cdot \mathrm{L}^{-1} \mathrm{~s}-\mathrm{ABA}\right.$ spray and drench $)(P \leq$ 0.05) (Fig. 4).

\section{Discussion}

Drought stress is a major cause of postproduction shrinkage in the floriculture industry (Barrett and Campbell, 2006). ABA applications resulted in reduced water loss under severe drought stress for all bedding plants treated. This reduction in water loss allowed impatiens, seed geraniums, petunias, marigolds, salvia, and pansies to tolerate temporary periods of drought stress similar to what they might experience during shipping and retailing. The ABA-induced delay in visual wilting symptoms resulted in shelf life extensions from 1.7 to $4.3 \mathrm{~d}$ depending on the species and method of application. s-ABA applications delayed wilting in impatiens, petunias, and salvia without the development of any negative side effects, and after rewatering, the treated plants were 


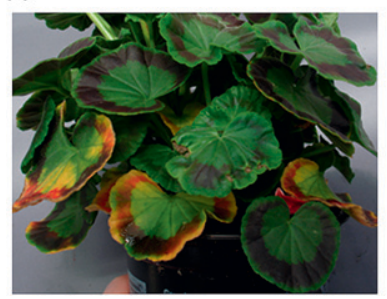

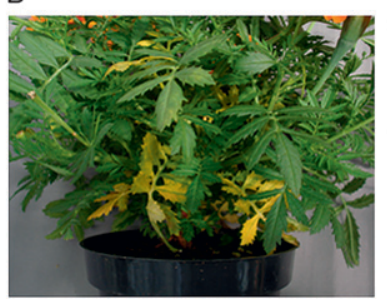

C

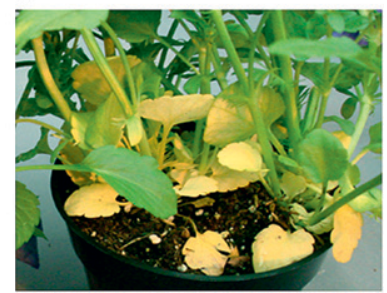

Fig. 3. Symptoms of leaf chlorosis were observed on Pelargonium $\times$ hortorum 'Maverick Red' (seed geraniums) (A), Tagetes patula 'Bonanza Orange' (marigolds) (B), and Viola $\times$ wittrockiana 'Bingo Rose Frost' (pansies) (C) after s-ABA application. Plants were treated with $500 \mathrm{mg} \cdot \mathrm{L}^{-1} \mathrm{~s}-\mathrm{ABA}$ spray and continually watered. Images are representative of leaf chlorosis symptoms observed after s-ABA applications. Leaf chlorosis ratings were from 1 to 11 with a rating of 11 being completely green with no sign of chlorosis, 10 : having $10 \%$ or less leaf chlorosis, $9: 11 \%$ to $20 \%, 8: 21 \%$ to $30 \%, 7: 31 \%$ to $40 \%, 6: 41 \%$ to $50 \%, 5: 51 \%$ to $60 \%, 4: 61 \%$ to $70 \%, 3: 71 \%$ to $80 \%, 2: 81 \%$ to $90 \%$, and $1: 91 \%$ to $100 \%$ chlorosis. Leaf chlorosis ratings of these images would be a 7 for seed geraniums (A), an 8 for marigolds (B), and a 7 for pansies $(\mathbf{C})$.

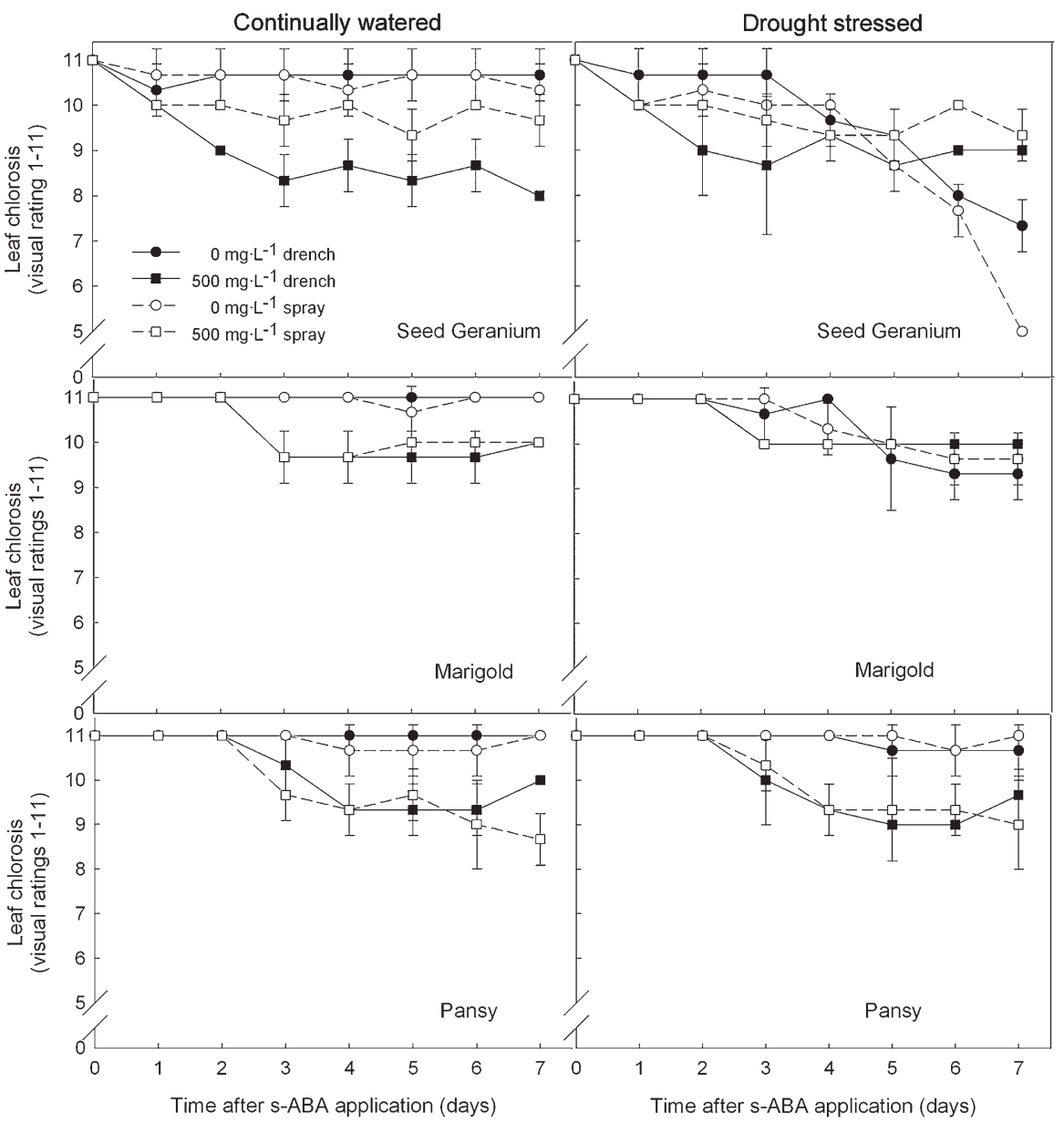

Fig. 4. Leaf chlorosis ratings of drought-stressed and continually watered finished plants. Plants were treated with 0 or $500 \mathrm{mg} \cdot \mathrm{L}^{-1} \mathrm{~s}-\mathrm{ABA}$ drench or spray. Pelargonium $\times$ hortorum 'Maverick Red' (seed geraniums), Tagetes patula 'Bonanza Orange' (marigolds) and Viola $\times$ wittrockiana 'Bingo Rose Frost' (pansies) were drought-stressed for $7 \mathrm{~d}$. Water was withheld until s-ABA-treated plants began to show visible symptoms of wilt. Leaf chlorosis ratings were from 1 to 11 with a rating of 11 being completely green with no sign of chlorosis, 10 : having $10 \%$ or less leaf chlorosis, $9: 11 \%$ to $20 \%, 8$ : $21 \%$ to $30 \%, 7: 31 \%$ to $40 \%, 6: 41 \%$ to $50 \%, 5: 51 \%$ to $60 \%, 4: 61 \%$ to $70 \%, 3: 71 \%$ to $80 \%, 2: 81 \%$ to $90 \%$, and $1: 91 \%$ to $100 \%$ chlorosis. Visual ratings were taken daily with Day 0 being just before s-ABA application $(n=4)$.

indistinguishable from continually watered plants. The application of s-ABA also enhanced the drought tolerance of seed geraniums, marigolds, and pansies, but symptoms of leaf chlorosis were observed that may reduce their salability.

Under our experimental conditions, s-ABA applications were most effective at delaying wilting symptoms in petunias and least effective in marigolds. Responses to ABA applications have been shown to vary based on the species (Blanchard et al., 2007; Sharma et al., 2006). Blanchard et al. (2007) reported that sprench applications of 125 and $250 \mathrm{mg} \cdot \mathrm{L}^{-1} \mathrm{~s}$ ABA were effective in extending the shelf life of New Guinea impatiens (Impatiens hawkeri 'Harmony Grape') for 4.3 to $5.8 \mathrm{~d}$ but were not effective in extending the shelf life of impatiens (Impatiens walleriana 'Tempo Lavender') or bacopa (Sutera cordata 'Cabana'). In all of the species that we evaluated, including impatiens (Impatiens walleriana 'Xtreme Lavender'), both spray and drench s-ABA applications resulted in shelf life extensions in drought-stressed plants. Differences in environmental conditions, s-ABA concentrations, and cultivar selection may explain the differences between the present study and reports published previously.

The method of s-ABA application affected the shelf life and the wilt status of some but not all species. At the end of our drought stress treatments, there were some differences in wilt status based on method of application for impatiens, petunias, and pansies, but this did not result in a significant difference in shelf life extension. Only in marigolds did one application method (drench) result in an extension in shelf life over the other method. In pepper seedlings, ABA applications to the leaves reduced plant growth more than applications to the roots (Leskovar and Cantliffe, 1992). Drought stress, at the whole plant level, is initially sensed in the roots where ABA is synthesized and translocated to the leaves through the xylem (Malladi and Burns, 2007). In the leaves, free ABA results in stomatal closure and reduced water loss. Recently it was reported that under severe drought conditions, plants also synthesize ABA in their leaves (Malladi and Burns, 2007). These findings suggest that $\mathrm{ABA}$ applications to the leaves may result in quicker and more effective stomatal closure than root applications. This response may be very speciesspecific. Only in drought-stressed pansies were the wilting symptoms less severe when plants were sprayed with s-ABA.

Along with some variability in wilt status and shelf life extension based on species and method of application, we also noticed variability in the occurrence of side effects. The only side effect we noticed during our experiment was leaf chlorosis, which occurred on three of the six species tested. Blanchard et al. (2007) reported that leaf chlorosis was observed on s-ABA-treated pansies, but there was no quantification of the severity of the response nor were any data presented for nondrought-stressed plants treated with sABA. Kim and van Iersel (2008) observed leaf abscission after applications of s-ABA to drought-stressed salvia (Salvia splendens 'Bonfire'). We did not, however, observe sABA or drought-induced leaf abscission in salvia or any other species that were evaluated. Drought stress-induced leaf chlorosis was not prevented in seed geraniums and 
marigolds treated with s-ABA, and chlorosis symptoms were the same or more severe in drought-stressed plants than well-watered plants treated with s-ABA. Only in pansies was it clear that the s-ABA treatment itself induced leaf chlorosis, because the droughtstressed plants in the absence of s-ABA $(0$ $\mathrm{mg} \cdot \mathrm{L}^{-1}$ controls) were not yellow. The leaf chlorosis observed in pansies may have resulted from increased synthesis or sensitivity to other senescence-related hormones, including ethylene. Exogenous applications of ABA have been shown to increase ethylene production and decrease cytokinins, which would induce leaf senescence (Nilsen and Orcutte, 1996; Taiz and Zeiger, 2002). Further evaluation of the ABA-induced leaf chlorosis in pansies is needed to determine the involvement of other hormones.

Applications of s-ABA were effective at delaying symptoms of wilting in severely drought-stressed plants. The use of s-ABA by floriculture producers would allow bedding plants to temporarily avoid drought stress-induced wilting during shipping and the first few days of retailing. Overall, this should increase the quality and aesthetic value of the plants so that postproduction shrinkage can be reduced and profits can be maximized for both retailers and growers.

\section{Literature Cited}

Armitage, A.M. 1993. Bedding plants: Prolonging shelf performance: Postproduction care and handling. Ball Publishing Co., Batavia, IL.

Barrett, J. and C. Campbell. 2006. S-ABA: Developing a new tool for the big grower. Big Grower 1:26-29.

Beach, S.E., T.W. Starman, K.L. Eixmann, H.B. Pemberton, and K.M. Heinz. 2009. Reduced end-of-production fertilization rate increased postproduction shelf life of containerized vegetative annuals. HortTechnology 19:158-167.

Blanchard, M.G., L.A. Newton, E.S. Runkle, D. Woodlard, and C.A. Campbell. 2007. Exogenous applications of abscisic acid improved the postharvest drought tolerance of several annual bedding plants. Acta Hort. 755:127-132.

Healy, W. 2009. Piles of money. GrowerTalks Magazine 72:42-46.

Kim, J. and M. van Iersel. 2008. ABA drenches induce stomatal closure and prolong shelf life of Salvia splendens. Southern Nursery Association Research Conference 53:107-111.

Leskovar, D.I. and D.J. Cantliffe. 1992. Pepper seedling growth response to drought stress and exogenous abscisic acid. J. Amer. Soc. Hort. Sci. 117:389-393.

Malladi, A. and J.K. Burns. 2007. Communication by plant growth regulators in roots and shoots of horticultural crops. HortScience 42:1113-1117.

Monteiro, J.A., T.A. Nell, and J.E. Barrett. 2001. Postproduction of potted miniature rose:
Flower respiration and single flower longevity. J. Amer. Soc. Hort. Sci. 126:134-139.

Nilsen, E.T. and D.M. Orcutte. 1996. Phytohormones and plant responses to stress, p. 183198. In: Nilsen, E.T. and D.M. Orcutte (eds.). The physiology of plants under stress: Abiotic factors. John Wiley and Sons, New York, NY.

SAS Institute, Inc. 2002-2003. SAS/STAT ${ }^{\text {TM }}$ user's guide. Version 9.1.3. SAS Institute, Inc., Cary, NC.

Sharma, N., S.R. Abrams, and D.R. Waterer. 2006. Evaluation of abscisic acid analogs as holding agents for bedding plant seedlings. HortTechnology 16:71-77.

Starman, T.W., S.E. Beach, and K.L. Eixmann. 2007. Postharvest decline symptoms after simulated shipping and during shelf life of 21 cultivars of vegetative annuals. HortTechnology 17:544-551.

Taiz, L. and E. Zeiger. 2002. Abscisic acid: A seed maturation and antistress signal, p. 539-558. In: Taiz, L. and E. Zeiger (eds.). Plant physiology. 3rd Ed. Sinauer Associates, Inc., Sunderland, MA.

USDA, 2009. Floriculture crops 2008 summary, Agricultural Statistics Board, NASS, USDA.

Yamazaki, H., T. Nishijima, and M. Koshioka 1995. Effects of $(+)-S$-abscisic acid on the quality of stored cucumber and tomato seedlings. HortScience 30:80-82.

Yue, C. and B.K. Behe. 2008. Estimating U.S consumers' choice of floral retail outlets. HortScience 43:764-769. 